\title{
Hamster Buccal Pouch Carcinoma
}

National Cancer Institute

\section{Source}

National Cancer Institute. Hamster Buccal Pouch Carcinoma. NCI Thesaurus. Code C134565.

Buccal pouch carcinoma that occurs in a hamster. 